\title{
Farmers' Perception of Soil Erosion and Adoption of Soil Conservation Technologies at Geshy Sub-Catchment, Gojeb River Catchment, Ethiopia
}

\author{
Melku Dagnachew Alemu1 ${ }^{*}$, Asfaw Kebede ${ }^{2}$, Awdenegest Moges ${ }^{3}$ \\ ${ }^{1}$ Natural Resources Management, Wolaita Soddo University, Wolaita Sodo, Ethiopia \\ ${ }^{2}$ Haramaya Institute of Technology, Haramaya University, Dire Dawa, Ethiopia \\ ${ }^{3}$ Hawassa Institute of Technology, Hawassa University, Hawassa, Ethiopia \\ Email: *melku1980@gmail.com, asfaw649@gmail.com, awde_moges@yahoo.co.uk
}

How to cite this paper: Alemu, M.D., Kebede, A. and Moges, A. (2019) Farmers' Perception of Soil Erosion and Adoption of Soil Conservation Technologies at Geshy Sub-Catchment, Gojeb River Catchment, Ethiopia. Agricultural Sciences, 10, 46-65. https://doi.org/10.4236/as.2019.101005

Received: December 4, 2018

Accepted: January 7, 2019

Published: January 10, 2019

Copyright () 2019 by author(s) and Scientific Research Publishing Inc. This work is licensed under the Creative Commons Attribution International License (CC BY 4.0).

http://creativecommons.org/licenses/by/4.0/

(c) (7) Open Access

\begin{abstract}
The study was conducted to investigate farmers' perception of soil erosion, participation and adoption of soil conservation technologies (SWC) in Geshy sub-catchment of Gojeb river catchment, Omo-Gibe basin, Ethiopia during 2016. The study is based on a detailed survey of 77 households using structured interviews, field observation and focus group discussion. Descriptive and chi-square statistics were applied to analyze factors that affected farmers' perceived soil erosion severity, participation and adoption options. The results revealed that about $79 \%$ of farmers perceived soil erosion problem and its consequences and $97.4 \%$ of them believed that it can be controlled. Almost all (97.4\%) farmers acknowledged the presence of SWC technologies and about $92.2 \%$ of them were participated in conservation activities voluntarily. Thus, $93.5 \%$ of them realized decreasing rate of soil erosion and $79.9 \%$ of them observed an increasing trend in soil fertility status. Consequently, $94.8 \%$ of them confirmed the potential of SWC technologies to halt land degradation and improve land productivity. Furthermore, $98.7 \%$ of them were willing to adopt with very good adoption judgment and $94.8 \%$ of them were willing to continue maintaining constructed technologies in the future. Principally, farmers' perception of soil erosion, their genuine participation derived from their conviction, and adoption of induced SWC technologies are the decisive elements for the success of watershed management interventions.
\end{abstract}

\section{Keywords}

Adoption, Perception, Soil and Water Conservation, Soil Erosion, 
Geshy Sub-Catchment, Ethiopia

\section{Introduction}

Land degradation, is a gradual, worldwide negative environmental process and development and causes the temporary or permanent decline in the productivity of land resources' capacity to perform their functions [1]. Land degradation, caused by multiple factors, both biophysical and human, is a persistent deterioration of land's productivity [1] [2]. Its processes have been observed across the world, including in South America [3], Asia [4] and Africa [5]. Particularly, Africa is the most vulnerable [6] in which $65 \%$ of crop land and $31 \%$ of pasture land are affected by land degradation [7]. Water erosion induced soil degradation in Sub-Saharan Africa (SSA) is of concern mainly because of its consequences for subsistence agriculture, from which about $75 \%$ of the population derives their livelihoods [8]. Among the SSA countries, Ethiopia is the most environmentally troubled country which has a high level of continued soil erosion problem that seriously threatens peoples' livelihoods [9] [10] [11]. These losses are primarily triggered by human activity that might be associated with rapid population growth and the need to maximize production [12]. The problems of land degradation and low agricultural productivity are severe in the rural highlands of Ethiopia that constitute $95 \%$ of the cultivable area and support $88 \%$ and $75 \%$ of the human and livestock population respectively [13]. Research findings revealed that the rate of soil erosion on cultivated lands across the country was $42 \mathrm{Mg} \cdot \mathrm{ha}^{-1} \cdot \mathrm{year}^{-1}$ [14] [15] [16]. Other studies [17] also estimated the rates of soil erosion as $20 \mathrm{Mg} \cdot \mathrm{ha}^{-1} \cdot \mathrm{year}^{-1}$ on currently cultivated lands and $33 \mathrm{Mg} \cdot \mathrm{ha}^{-1} \cdot \mathrm{year}^{-1}$ on formerly cultivated degraded lands in Ethiopia. Moreover, studies elsewhere [18] [19] reported a soil erosion rate of 47 and $93 \mathrm{Mg} \cdot \mathrm{ha}^{-1} \cdot \mathrm{year}^{-1}$ in Koga and Chemoga watershed respectively. Studies in Shomba sub-catchment also indicated that the estimated mean annual rate of soil erosion in cultivated fields was 13.5 ton $\cdot \mathrm{ha}^{-1} \cdot \mathrm{yr}^{-1}$ that accelerates its rate beyond the tolerable level [20].

Recognizing land degradation as a major environmental and socio-economic problem, the government of Ethiopia has planned and made several interventions to promote and invest in SWC interventions that consider unique conditions of the different agro-ecological zones in the first (2005/06-2009/10) and second (2015/16-2020/21) growth and transformation plan. Accordingly, sustainable land management (SLM) program has been launched since 2008 with the ambitious of improving agricultural productivity, environmental rehabilitation and food security. In Ethiopia, to grapple with the problem of soil erosion and improve peoples' livelihoods, large-scale conservation schemes to promote SWC technologies were initiated [11] [15] [21] [22]. Despite the successes, some studies claimed that the SWC programme in the country did not succeed in triggering voluntary adoption of conservation practices [23] [24]. Furthermore, 
reports [8] [14] [15] have indicated a relatively low level of success and weak evaluation in terms of environmental, socio-economical and cultural perspectives. The reasons for failed adoption of SWC interventions by farmers are lack of farmers' perception of soil erosion, participation and adoptions conservation technologies and poor extension approaches, lack of incorporating indigenous technologies [24], land tenure insecurity, the inability to make SWC productive and high cost demanding of interventions [25] and uniform application of similar SWC measures disregarded agro-ecological variations [26].

Farmers' perception of soil erosion is a key social factor that plays a great role in their decision making on land management practices for controlling soil losses. It affects the selection and continued use of soil conservation practices [10]. Hence, better understand the factors that influence the adoption of SWC technologies has become an important concern which has been stemmed from the high rate of land degradation. The existing studies on those factors that determine adoption are scanty and non-existing in Geshy sub-catchment. Some authors [9] [23] in Ethiopia reported that farmers are more likely to adopt conservation measures in plots that are highly prone to soil erosion. Study by [24] concluded that under current conditions, SWC interventions should consider farmers' conservation knowledge and practices to improve the possibility of acceptance and adoption of the recommendations. Among the SLM intervention watersheds in Ethiopia, Geshy sub-catchment is the one in which farmers have been suffering from the impacts of severe soil erosion due to lack of perceptions on soil erosion, and lack of active participation and adoption options in SWC practices [20]. Consequently, farmers are forced to expand their farmlands to forestlands and marginal areas which are characterized by rugged topography. Hence, evaluating the success and/or failure stories of SWC technologies will have a paramount importance in the overall status of the costly implemented SLM programs and are still lacking due to lack of scientific evidence on farmers' perception of soil erosion and their adoption strategies of SWC technologies. Therefore, the objective of this study was to assess farmers' perception on soil erosion and adoption of soil and water conservation technologies in Geshy sub-catchment of Gojeb river catchment, Omo-Gibe basin, Ethiopia.

\section{Materials and Methods}

\subsection{Description of the Study Area}

The study was conducted in Geshy sub-catchment of Gojeb river catchment, Omo-Gibe basin, Ethiopia which covers a total area of 9628.5 ha. Geographically, it lies between $07^{\circ} 22^{\prime}-7^{\circ} 26^{\prime} \mathrm{N}$ latitude and $36^{\circ} 12^{\prime}-36^{\circ} 24^{\prime} \mathrm{E}$ longitude with altitude ranges from 1600 to 1800 m.a.s.l. (Figure 1).

Agro-ecologically, it falls in the wet/moist (woina dega) regime and is found in warm sub-moist lowlands and tepid sub-moist mid highlands and tepid humid to sub-humid mid highlands, and warm sub-humid lowlands [27].

The rainfall is uni-modal with low rainfall from November to February and 


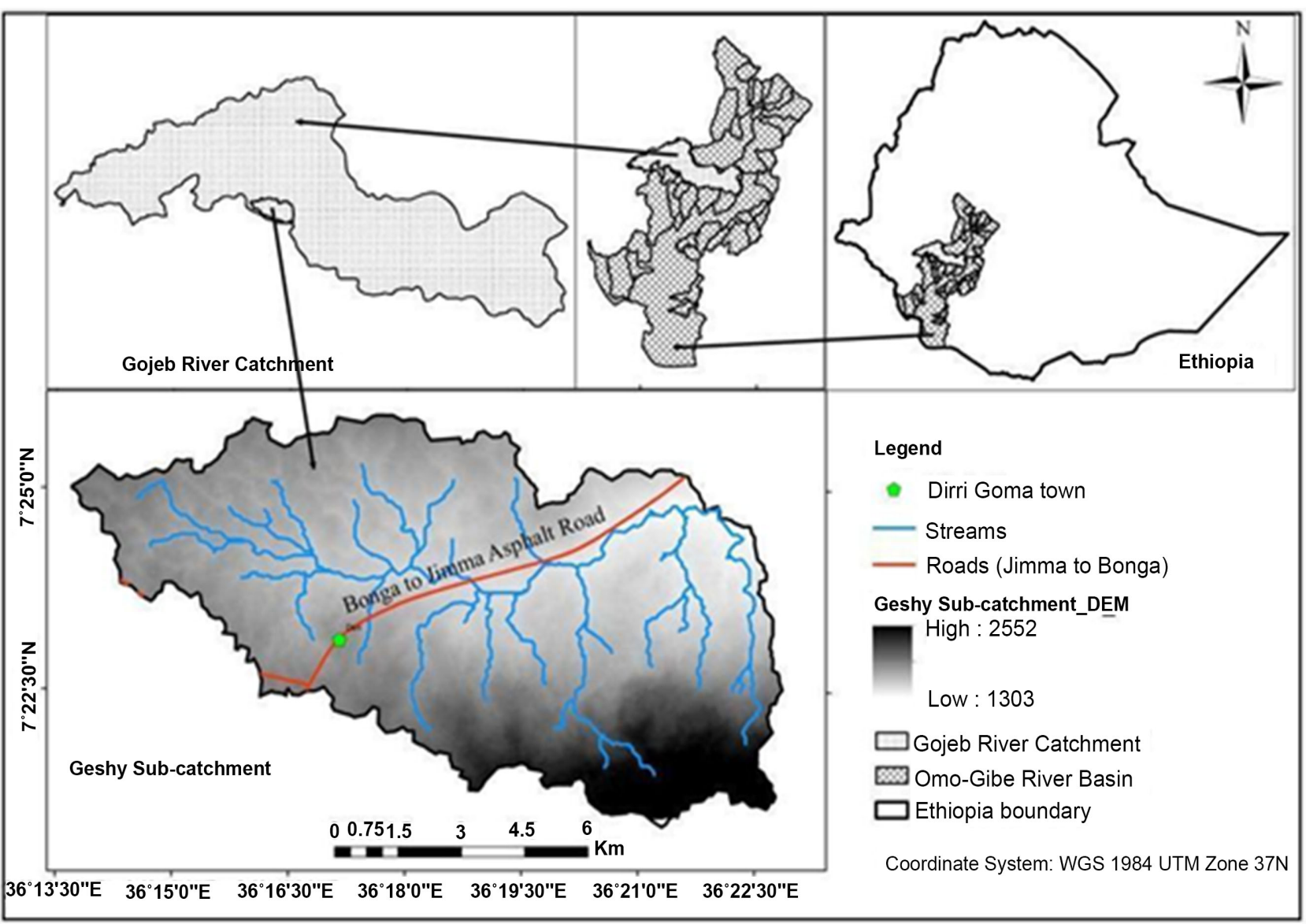

Figure 1. Study map of Geshy sub-catchment, Gojeb River Catchment, Ethiopia.

the wettest months between May and September. The mean annual and monthly rainfall of $1762 \mathrm{~mm}$ and $136.3 \mathrm{~mm}$ and monthly mean maximum and minimum temperature of $25.3^{\circ} \mathrm{C}$ and $15^{\circ} \mathrm{C}$ (Figure 2), respectively, was recorded at Dirri meteorological station. In the study area, five major soil types, namely: Fluvisols, Cambisols, Vertisols, Regosols and Leptosols have been identified [27]. The land use pattern is characterized by extensive cropland and mainly dominated by cropland, forestland, shrublands, woodland, and swamp area [20]. The total population in Geshy sub-catchment is 14518 from which 7261 are men with total number of households 3060 from which 2793 men [27].

\subsection{Methods}

\subsubsection{Data Collection Method}

In this study, the major sources of both quantitative and qualitative data were the primary and secondary sources. The primary data were collected from sample respondents through structured and semi-structured questionnaire. Primary data were generated by means of field observation, key informants, focus group discussion and structured questionnaires and interview with were da (district) agricultural experts, local community leaders, and development agents to bring the study to fruition. The household survey was employed to collect a range of 


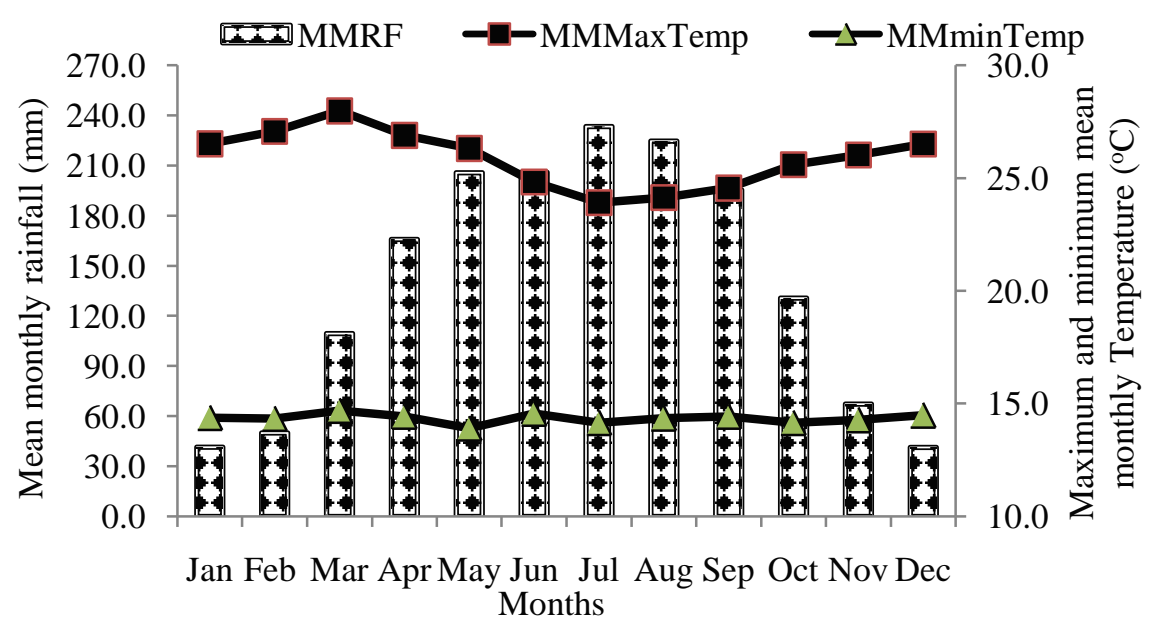

Figure 2. Mean monthly precipitation $(\mathrm{mm})$ and mean monthly maximum and minimum temperature $\left({ }^{\circ} \mathrm{C}\right)$ at Dirri meteorological station, Geshy sub-catchment.

quantitative data on household and land characteristics, farmers' perception of soil erosion, and their adoption options by interviewing sample household heads. First, sample kebeles (smallest administrative units) were selected from upstream, midstream and downstream reach of Geshy sub-catchment. Then, lists of households in each of the villages were obtained from the respective kebele administrative office and village leaders. With the lists, sample households were drawn using a systematic random sampling procedure. In doing so, sampling interval $(\mathrm{K})$ was determined by dividing the total number of households in the population by the desired sample size of each kebele. Next, a number was selected between one and the sampling interval $(\mathrm{K})$ using lottery method, which is called the random start that was used as the first number included in the sample. Then, every $\mathrm{K}^{\text {th }}$ household head after that first random start was taken until reaching the desired sample size for each kebele that represent the upper, middle and lower positions. In case where a selected household happened to be away from home for a long time or was unwilling to be interviewed, a randomly selected substitute was included. Kothari [28] statistical formula was used for the determination of the sample size for a better representation of the population proportion. Accordingly, a total of 77 respondents were drawn proportionally from the sampled kebeles out of a population of 967 registered farmers and sit for interviews at their residence. A semi-structured questionnaire was used for the field interviews. The survey questionnaires were comprised of both closed and open-ended types of questions, thereby providing respondents with an opportunity to express their views without being restricted by pre-coded response options. The semi-structured questionnaire for the actual household surveys was administered by data collectors with close supervision of the researcher. Data collectors were trained with respect to the survey techniques and confidentiality protocol. After training, the data collectors acquired practical experience while we were making face-to-face interview in the actual data collection in the field. The questionnaire was pre-tested by administering it to selected respondents. 
On the basis of the results obtained from the pre-test, necessary modifications were made on the questionnaire. The interviews were conducted by going to each interviewee's homestead.

Key informants with kebele ${ }^{1}$ administrative officials, community elders, experts and development agents of Wereda agriculture and natural resources offices and randomly selected well known farmers were interviewed from both up, mid and downstream watershed positions. They were interviewed using semi-structured interview method with open-ended checklists of topics to guide the sessions in an orderly manner and farmers for the flexibility it allows and the possibility to explore some newly emerging issues. Focus group discussion (FGD) was also made and is usually believed to be powerful in eliminating exaggerated opinions that may be expressed, as participants were checked by each other. These informal techniques helped to acquire useful and detailed information, which will be difficult to collect information through the questionnaire survey. The FGD which included 7 to 10 farmers in a group were carried out in each up, mid and downstream of the sub-catchment based on their landholding, farm experiences, farm characteristics, age and sex. Discussions with women and youth groups were carried out in each positions of the sub-catchment. The major issues of the discussions were farmers' perception of soil erosion and their level of participation, knowledge and adoptions options of soil conservation technologies. A checklist was prepared to guide the open-ended discussion with identified FGD members. The interview was held with community leaders and knowledgeable persons in the community. Information obtained from the interview and from the group discussions was checked for consistency and also used to supplement one another. Additionally, secondary data were obtained from published journals and unpublished thesis, dissertations, reports, proceedings, and internet sources.

\subsubsection{Data Analysis}

The quantitative data that were generated by the structured questionnaires were analyzed using IBM SPSS Statistics for Windows, Version 20.0 [29]. The descriptive and chi-square statistics were used to test significance of relationships between household characteristics and farmers' perception, willingness to participate and adoption. The qualitative data that were generated by the informal and focus group discussions was used to substantiate and augment the quantitative analysis of the structured questionnaires.

\section{Results and Discussion}

\subsection{Household Characteristics}

Table 1 and Table 2 present basic household and socio-demographic characteristics of the sample households in Geshy sub-catchment. The overall mean family size, 5.88 persons per household was above the average family size of 4.9 ${ }^{1}$ The lowest administrative level within a district or Wereda. 
Table 1. Basic household characteristics.

\begin{tabular}{cccccc}
\hline \multicolumn{5}{c}{ Descriptive Statistics } \\
\hline Item descriptions & $\mathrm{N}$ & Minimum & Maximum & Mean & Std. Deviation \\
\hline Age of respondent & 77 & 25 & 75 & 47.55 & 11.53 \\
Family size & 77 & 2 & 14 & 5.88 & 2.27 \\
Landholding size (Ha) & 77 & 0.25 & 25.00 & 3.37 & 3.37 \\
Period of residence (years) & 77 & 9 & 64 & 35.03 & 10.82 \\
Livestock size & 77 & 0 & 31 & 7.51 & 5.72 \\
\hline
\end{tabular}

Table 2. Socio-demographic characteristics of HHs in Geshy sub-catchment.

\begin{tabular}{|c|c|c|c|c|c|}
\hline $\begin{array}{c}\text { Item } \\
\text { description }\end{array}$ & $\begin{array}{c}\text { Frequency } \\
(\mathrm{N}=77)\end{array}$ & $\begin{array}{l}\text { Percent } \\
(\%)\end{array}$ & Item description & $\begin{array}{c}\text { Frequency } \\
(\mathrm{N}=77)\end{array}$ & $\begin{array}{c}\text { Percent } \\
(\%)\end{array}$ \\
\hline \multicolumn{3}{|c|}{ Sex } & \multicolumn{3}{|c|}{ Marital Status } \\
\hline Male & 71 & 92.2 & Married & 75 & 97.4 \\
\hline Female & 6 & 7.8 & Widow & 2 & 2.6 \\
\hline \multicolumn{3}{|c|}{ Age (years) } & \multicolumn{3}{|c|}{ Educational level } \\
\hline$<30$ & 4 & 5.2 & Illiterate & 30 & 39.0 \\
\hline $30-40$ & 22 & 28.6 & Read \& Write & 10 & 13.0 \\
\hline $41-50$ & 18 & 23.4 & $1-4$ grade & 16 & 20.8 \\
\hline $51-65$ & 30 & 39.0 & 5 - 8 grade & 16 & 20.8 \\
\hline$>65$ & 3 & 3.9 & $9-12$ grade & 5 & 6.5 \\
\hline \multicolumn{3}{|c|}{ Family size } & \multicolumn{3}{|c|}{ Period of residence (years) } \\
\hline $0-2$ & 5 & 6.5 & $<10$ & 2 & 2.6 \\
\hline $3-5$ & 33 & 42.9 & $11-20$ & 5 & 6.5 \\
\hline $6-8$ & 32 & 41.6 & $21-30$ & 31 & 40.3 \\
\hline$>8$ & 7 & 9.1 & $>30$ & 39 & 50.6 \\
\hline
\end{tabular}

The main sources of household income

$\begin{array}{lcc}\text { On-farm } & 54 & 70.1 \\ \text { Off-farm } & 0 & 0\end{array}$

Both (on \& off-farm) 23

Landholding size (ha)

$\begin{array}{ccc}<1 & 19 & 24.7 \\ 1-3 & 34 & 44.2 \\ 3.10-7 & 19 & 24.7 \\ 7.10-10 & 4 & 5.2 \\ >10 & 1 & 1.3\end{array}$

Landholding size adequacy

$\begin{array}{ccc}\text { Adequate } & 24 & 31.2 \\ \text { Inadequacy } & 52 & 67.5 \\ \text { No opinion } & 1 & 1.3\end{array}$

29.9
Are you currently involved in local administration?

$\begin{array}{lll}\text { Yes } & 25 & 32.5 \\ \text { No } & 52 & 67.5\end{array}$

Relative position in the watershed

$\begin{array}{ccc}\text { Upstream } & 25 & 32.5 \\ \text { Midstream } & 25 & 32.5 \\ \text { Downstream } & 27 & 35.1\end{array}$

Farming system

$\begin{array}{ccc}\text { Crop only } & 14 & 18.2 \\ \text { Livestock } & 1 & 1.3 \\ \text { Mixed } & 62 & 80.5\end{array}$


persons per household [30]. Similar to all rural area of Ethiopia, land is the most important livelihood asset for the surveyed households. The landholding size of the respondents ranged from 0.25 to 25 ha with an average of about 3.37 ha, which is by far larger than the 2007 national average of 0.85 ha [30]. The majority of the respondents (44.2\%) however possessed 1.0 to 3.0 ha followed by less than 1 ha $(24.7 \%)$ and 3.1 to 7 ha $(24.7 \%$ and only $1.3 \%$ possessed more than 10 ha of land). Despite the landholding size is by far above the national average, most of them (about 67.5\%), acknowledged that their holdings were increasingly inadequate to support their households because of rural population growth, soil erosion, and declining land productivity. The respondents have used to live for an average of about 35 years, of which the majority of them (50.6\%) were lived more than 30 years which made them to have basic knowledge about the environmental problems in the area.

In the study area, the majority of respondents (39\% of total) were illiterate with only $6.5 \%$ of them having secondary school education ( 9 - 12 grades). Both age and literacy levels have implications for the respondents' perception and adoption of soil erosion and conservation. Furthermore, unlike the majority (67.5\%) of farmers, some $32.5 \%$ of them were involved in local administrations. This is critically important because the involvement affords farmers a measure of social status as well as access to critical land management and farming information. Moreover, $70.1 \%$ of respondents' livelihood entirely depends on on-farm activities and their major farming system is crop-livestock mixed (80.5\%), while $18.2 \%$ of the households used to practice crop only and very few of them (1.3\%) used to herd livestock only. This might have an implication on the dependency of farmers on natural resources for their agricultural expansion.

\subsection{Farmers' Perception on Soil Erosion and Soil Fertility, Geshy Sub-Catchment}

In Geshy sub-catchment, farmers' perception of soil erosion was presented in Table 3. A farmer's awareness of soil erosion is consequently a critical parameter for their willingness to adopt. The majority of the respondents (79.2\%) perceived soil erosion as a problem constraining their crop production and lead serious land degradation, while the rest $20.8 \%$ didn't perceived it as a problem, this might be due to its gradual and unseen nature of the progress. The results obtained from the individual farmers and focus group discussion revealed that the main causes of soil erosion were deforestation due to agricultural expansion, heavy and long rainy season, steepness of their cropland and runoff coming from the upslope area. Similarly, soil erosion still remains a significant problem in large parts of Ethiopia due to the forecasted increase in population and extreme precipitation events [16]. The major consequences of soil erosion understood by the respondents are loss of soil fertility $(67.5 \%)$, the decline in land productivity $(22.5 \%)$, followed by creation of rill and gullies $(7.5 \%)$ on their farm land. They also reported that the most important topsoil for crop production 
Table 3. Farmers' perception on soil erosion and fertility in the study area $(\mathrm{N}=77)$.

\begin{tabular}{|c|c|c|}
\hline Item description & Frequency $(\mathrm{N}=77)$ & Percent (\%) \\
\hline \multicolumn{3}{|c|}{ Do you perceive soil erosion in your own farmland? } \\
\hline Yes & 61 & 79.2 \\
\hline No & 16 & 20.8 \\
\hline \multicolumn{3}{|c|}{ What is the severity of soil erosion? } \\
\hline Severe & 23 & 29.9 \\
\hline Moderate & 18 & 23.4 \\
\hline Minor & 21 & 27.3 \\
\hline No erosion & 15 & 19.5 \\
\hline \multicolumn{3}{|c|}{ What do you think the possible consequences of soil erosion? } \\
\hline Loss of soil fertility & 52 & 67.5 \\
\hline Decline in land productivity & 17 & 22.1 \\
\hline Change of crop types & 2 & 2.6 \\
\hline Creation of rills, gullies & 6 & 7.8 \\
\hline \multicolumn{3}{|c|}{ The possible causes of soil erosion are? } \\
\hline Deforestation & 36 & 46.8 \\
\hline Slopes being steep & 26 & 33.7 \\
\hline Too much rainfall & 5 & 6.5 \\
\hline Runoff from upslope & 10 & 13.0 \\
\hline \multicolumn{3}{|c|}{ Perceptions on the trends of soil erosion rate? } \\
\hline Become more severe & 13 & 16.9 \\
\hline Become less severe & 61 & 79.2 \\
\hline No change & 3 & 3.9 \\
\hline \multicolumn{3}{|c|}{ Expectation in soil erosion severity changes in the future? } \\
\hline Will get worse & 12 & 15.6 \\
\hline will get better & 60 & 77.9 \\
\hline will remain same & 2 & 2.6 \\
\hline Don’t know & 3 & 3.9 \\
\hline \multicolumn{3}{|c|}{ Perceptions on the trend of fertility of your land? } \\
\hline Decreasing rate & 11 & 14.3 \\
\hline Increasing rate & 60 & 77.9 \\
\hline No change & 6 & 7.8 \\
\hline \multicolumn{3}{|c|}{ How do you rate the soil fertility status of your farmland? } \\
\hline High fertility & 12 & 15.6 \\
\hline Medium fertility & 60 & 77.9 \\
\hline Poor fertility & 5 & 6.5 \\
\hline \multicolumn{3}{|c|}{ Do you think that erosion can be controlled? } \\
\hline Yes & 75 & 97.4 \\
\hline No & 2 & 2.6 \\
\hline
\end{tabular}


was deteriorating and reducing the depth of the topsoil over time due to erosion. Other studies indicated that soil erosion problem has been widely recognized by farmers [9] [14] [31].

In the study area, the respondents were able to rate the extent of soil erosion problem as severe $(29.9 \%)$, minor $(27.3 \%)$, moderate $(23.4 \%)$; while, $19.5 \%$ of them were not perceived its severity. The majority of them (79.2\%) hoped that the trends of soil erosion rate will become less severe following the implementation of sustainable land management practices. Accordingly, $77.9 \%$ of them expected that the severity of soil erosion will get better, while $15.6 \%$ perceived the severity will get worse followed by will remain the same (2.6\%) but only $3.9 \%$ don't know. Generally, almost all of them (97.4\%) believed that soil erosion can be controlled and they could control erosion on their farm plots. In line with our finding, various studies [14] [20] [24] [32] [33] reported that the majority of farmers confirmed that erosion can be controlled.

The link between soil erosion and decline in soil fertility levels appeared to be obvious to the respondents because the declining soil fertility was attributed to "over cultivation" caused by overuse and occurrence of soil erosion. Some of the interviewed farmers (14.3\%) and those who participated in the focus group discussion confirmed that there have been a decline in soil fertility and land productivity in their farm plots over time. Unlike the previous time, the majority of farmers (77.9\%) confirmed that they observed an increasing trend in the soil fertility status following the introduction of soil conservation practices. Field observation and group discussion also indicated that farmers undertook a range of practices for soil fertility maintenance: crop rotation; application of organic matter (animal manure, compost, household wastes, and crop residues); use of chemical fertilizers; and erosion control practices.

The reason for the increasing trend of soil fertility might be attributed to the integrated use of both organic and inorganic fertilizers. Accordingly, the majority of the respondents (61\%) used both organic and inorganic fertilizer simultaneously; while $19.5 \%$ and $16.9 \%$ of them used only organic and inorganic fertilizers respectively, but only $2.6 \%$ of them were used none of these. Moreover, the majority of them (58.8\%) confirmed that the fertility of their land has been improved and rated the soil fertility status of their land as medium (77.9\%), followed by high (15.6\%) and low (6.5\%) which might indicated their awareness on the positive effects of organic fertilizers in improving soil quality and reduced runoff. However, farmers in the study area used to collect cow dung and crop residues from their land for fuel and hatching which limited the use of organic matter and resulted in the deterioration of biological processes in the soil. In the study area, among household characteristics, the most significant factors influencing farmers' perception of soil erosion were farming system $\left(\chi^{2}=13.845, \mathrm{P}\right.$ $=0.001)$, and income sources $\left(\chi^{2}=5.379, \mathrm{P}=0.020\right)$; but $\operatorname{sex}\left(\chi^{2}=3.375, \mathrm{P}=\right.$ $0.066)$, educational level, relative position $\left(\chi^{2}=5.398, \mathrm{P}=0.067\right)$ and their involvement in local administration $\left(\chi^{2}=3.673, \mathrm{P}=0.055\right)$ didn't influence them. 
While, perceived trend of soil erosion rate was significantly affected by farmers' relative positions in the catchment $\left(\chi^{2}=11.648, \mathrm{P}=0.020\right)$, and land holding adequacy $\left(\chi^{2}=25.213, \mathrm{P}=0.000\right)$ of respondents. Moreover, the severity of soil erosion was significantly influenced by their farming system $\left(\chi^{2}=21.642, \mathrm{P}=\right.$ $0.001)$, income source $\left(\chi^{2}=12.901, \mathrm{P}=0.005\right)$, relative position $\left(\chi^{2}=15.763, \mathrm{P}=\right.$ 0.015). Similarly, their expectations in soil erosion severity changes in the future were significantly influenced by farming system $\left(\chi^{2}=23.895, \mathrm{P}=0.001\right)$, income sources $\left(\chi^{2}=8.656, \mathrm{P}=0.034\right)$, landholding size adequacy $\left(\chi^{2}=12.582, \mathrm{P}=\right.$ $0.050)$ and relative position $\left(\chi^{2}=19.674, \mathrm{P}=0.003\right)$. This finding concurs with similar studies across different parts of Ethiopia [9] [24] [34] findings that farmers have a holistic understanding of the attendant soil erosion and their management methods as integral to soil degradation.

\subsection{Farmers' Participation in Soil and Water Conservation Activities, Geshy Sub-Catchment}

In Geshy sub-catchment, farmers have been used to practice both indigenous and introduced SWC measures to conserve and maintain their farm land. The physical measures, mainly soil bund and Fanya juu, have been practiced by integrating them with multipurpose biological measures such as vetiver grass (Vetiverial zizanioides), Desho grass (Pennisetum pedicelluatum), and elephant grass (Pennisetum purpureum). Besides the stabilization of soil bund, they also used as thatching house, mulch material and forage for animals. Constructions of the physical SWC measures are costly and highly labour-intensive task to accomplish only by the effort of subsistence farmers. During field work and focus group discussion, we observed that farmers were involved in physical works in mass, while development agents were working as "facilitators" and wereda (district) agricultural officers were working as superintendent. It is realized that farmers were not allowed to be absent; otherwise they would be subjected to serious punishment. The conservation effort is truly meritorious, but only if it is really effective and can be sustainable. To be effective, it has to be carefully engineered; and to be sustainable, committed participation of the stakeholders-the farmers are crucial. Community participation is one of the factors assumed in this study as influencing the degree of adoption of soil conservation measures by farmers. If one needs to achieve success in conservation activities, farmers' active participation should be ensured from the beginning [25] [35]. Hence, farmers' willingness to participate in SWC activities should be examined in their communities.

The descriptive statistics on farmers' participation in SWC activities in Geshy sub-catchment was shown in Table 4 . The majority of respondents $(92.2 \%$ of the total) were participated in the SWC activities and only $7.8 \%$ of them were not participated. Accordingly, most of the respondents (87\%) were participated voluntarily, while the remainder, 6.5 percent of them participated simply because they were forced to do so by the kebele administration and development 
Table 4. Farmers' participation on SWC measures, Geshy Sub-catchment.

\begin{tabular}{ccc}
\hline Item description & Frequency & Percent \\
\hline Are you participating in SWC activities? & \\
Yes & 71 & 92.2 \\
No & 6 & 7.8 \\
How are you participating in SWC activities? & 67 & \\
Voluntarily & 5 & 6.0 \\
Forced to participate & 5 & 6.5 \\
Not involved & 5 & \\
\hline
\end{tabular}

agents. But, the rest 6.5 percent were not participated in any of the activities. The implementation of SLM program might play a vital role in motivating the community in participation of SWC activities. Since the majority of respondents were participated voluntarily, it becomes clear that SWC works are taking into account participatory approach as it is one of the basic principles of community based participatory watershed management. Similar study in the Northern part of Ethiopia [35] indicated that the newly introduced SWC measures have got good perception, acceptance and widely practiced by farmers. In contrary to our findings, studies [14] [33] revealed that only 35 - 40 percent of the interviewed farmers participated in the SWC works voluntarily. On the contrary to our finding, they concluded that where the majority felt coerced to participate which did not take into account participatory principles. In the study area, our findings revealed that among basic household socio-economic characteristics, only sex, educational level and period of residence have significantly influenced both farmers' level of participation and how they were participating in SWC activities. Since, the numbers of females headed respondents were very much less than the male respondents, the chi square test indicated a significant association between respondents' sex and their participation as they are dependent to each other. The majority of male headed household are willing to participate in SWC activities voluntarily than female headed households. The Chi-square test result showed a significant relationship between farmers' educational level and level of participation $\left(\chi^{2}=9.267, \mathrm{P}=0.050\right)$ as well as how they were participating in SWC activities $\left(\chi^{2}=19.001, \mathrm{P}=0.015\right)$. Those farmers who have been used to live for long time were found to be significantly higher level of participation $\left(\chi^{2}=7.991, \mathrm{P}=\right.$ $0.046)$ and more willing to participate voluntarily in SWC activities $\left(\chi^{2}=12.270\right.$, $\mathrm{P}=0.056)$ that might be attributed to continued awareness. Similar findings also reported by [36] [37]. In the contrary, other scholars revealed that age has a profound effect on farmers' participation in SWC activities [31] [38].

\subsection{Farmers' Knowledge and Adoption of SWC Technologies, Geshy Sub-Catchment}

The descriptive statistics of farmers' knowledge and adoption of SWC technologies was shown in Table 5. In the study sub-catchment, most of the respondents 
Table 5. Farmers' knowledge, acceptance and adoption of SWC technologies.

\begin{tabular}{|c|c|c|}
\hline Item description & Frequency & Percent (\%) \\
\hline \multicolumn{3}{|c|}{ Did you know the introduced SWC technologies before? } \\
\hline Yes & 53 & 68.8 \\
\hline No & 24 & 31.2 \\
\hline \multicolumn{3}{|c|}{ Who is responsible to construct and maintain the structures? } \\
\hline Community participation & 23 & 29.9 \\
\hline Family labor & 51 & 66.2 \\
\hline Financial incentives & 1 & 1.3 \\
\hline Labor exchange & 2 & 2.6 \\
\hline \multicolumn{3}{|c|}{$\begin{array}{l}\text { How do you compare the problem of soil erosion in your farm plots after conservation } \\
\text { structures were built? }\end{array}$} \\
\hline Increased & 3 & 3.9 \\
\hline Decreased & 72 & 93.5 \\
\hline I don't know & 2 & 2.6 \\
\hline \multicolumn{3}{|c|}{ Are the newly introduced SWC technologies effective in arresting soil erosion? } \\
\hline Yes & 75 & 97.4 \\
\hline No & 2 & 2.6 \\
\hline \multicolumn{3}{|c|}{ How is the status (degree) of use of improved SWC structures? } \\
\hline Totally removed & 6 & 7.8 \\
\hline Partially removed & 32 & 41.6 \\
\hline Modified (adapted) & 26 & 33.8 \\
\hline Not removed & 13 & 16.9 \\
\hline \multicolumn{3}{|c|}{ What is your adoption judgment of SWC measures? } \\
\hline Very good & 44 & 57.1 \\
\hline Good & 32 & 41.6 \\
\hline Poor & 1 & 1.3 \\
\hline
\end{tabular}

(94.8\%) had been getting extension service by developments agents, though the frequency of visiting varied with individual farmers. The acceptance of adoption is the decision to implement SWC measures or not, first of all farmers should know and aware of the relevance of introduced SWC technologies. Farmers' decisions to conserve soil and water resources are largely determined by their knowledge of the erosion problems and perceived benefits of conservation. The success of any SWC intervention depends on the extent to which the introduced conservation measures are accepted and adopted by the farming community [24] [25]. In other words, acceptance and farm-level adoption of the newly introduced conservation measures by the farmers is the decisive element for the success of a watershed management intervention [25] [39]. In this study context, acceptance refers to the farmers' evaluation of the introduced SWC technologies in terms of their effectiveness in arresting soil erosion and their potential to improve land productivity; while adoption refers to the farmers' expression of commitment for a sustained utilization of the technologies as part of the local 
agricultural system after the external assistance is withdrawn.

In the study area, almost all of the respondents (97.4\%) knew about the presence of introduced SWC measures such as soil/stone bund, Fanya juu (Table 5). Surprisingly, unlike some $(31.2 \%)$ of the respondents, the majority of them $(68.8 \%)$ were aware of the introduced SWC measures before the implementation of SLM program. They also confirmed that introduced SWC technologies (soil bund (46.8\%), Fanya juu (23.4\%) and afforestation (22.1\%)) are the most efficient technologies in arresting soil erosion. Moreover, farmers were also asked to compare the problem of soil erosion in their farm plots after conservation structures were built; accordingly, the majority of them (93.5\%) confirmed that soil erosion rate had decreased after the implementation of SLM program. Besides, almost all of them (94.8\%) believed that the new SWC technologies had the potential to improve land productivity and lead to increased crop yields. Similar findings elsewhere [24] [25] [32] [33] reported that the introduced SWC technologies had the potential to improve land productivity and control erosion.

Farmers who had been tried to implement conservation measures in their plots were interviewed to determine how they had measured the effectiveness of SWC technologies. Accordingly, they had already observed better growth and development of crops, particularly along the structures where fertile sediments were trapped. They also evaluated that the amount of sediment trapped by the structure was very high and would have been lost from the field had that conservation structure not been built. Furthermore, during group discussion, participants who treated their lands by conservation structures gave witness to the group that the technology they have been using improved their land productivity and obtained more yield than before. Therefore, farmers were able to differentiate indicators of "acceptance" such as knowledge about introduced SWC technologies, its effectiveness in arresting soil erosion as well as its potential to improve land productivity. On the other hand, acceptance of the technologies as effective measures against soil erosion and as having potential to improve land productivity cannot warrant its adoption at the farm level. While acceptance depends more on the design characteristics of technologies as related specifically to its effectiveness in arresting soil loss, farm level adoption of the technologies depends also on several socioeconomic and institutional factors [25].

Adoption of SWC technologies is a difficult concept to measure. The factors affecting adoption determine the sustainable utilization of the measures by the farmers [24] [40]. Hence, the newly introduced technologies can be considered as adopted if the land users (farmers) continue to utilize them as a part of their production system after the external assistance is withdrawn. In the study area, almost all the respondents (98.7\% of the total) showed willingness to adopt SWC measures. However, despite their interest, farmers were asked about the status (degree) of use of improved SWC structures. Accordingly, they responded that partially removed $(41.6 \%)$, while $33.8 \%$ of them replied that the structures were modified (adopted); whereas, only few $(7.8 \%)$ of them were totally removed. 
Results obtained from observation and group discussion showed that construction of introduced SWC measures were time-consuming, high labour-demanding and need frequent technical support for design construction. In the study area, almost all of the respondents (97.4\%) believe that construction and maintenance of SWC is their responsibility. They also added that family labour (66.2\%), community participation (29.9\%), labour exchange (2.6\%) and financial incentives (1.3\%) were the most important means to construct and maintain the SWC structures. Moreover, almost all respondents (94.8\%) expressed their willingness to continue maintaining the established structure and most of their adoption judgment of SWC measures was very good (57.1\%) and good (41.6\%) (Table 5).

In the study area, the sex of respondents was the potential factors that significantly influence the farmers' knowledge about the presence of SWC structures $\left(\chi^{2}=24.298, \mathrm{P}=0.000\right)$; provision of extension service $\left(\chi^{2}=10.461, \mathrm{P}\right.$ $=0.001)$ as well as their frequency of being visited by development agents $\left(\chi^{2}=\right.$ $12.713, \mathrm{P}=0.013)$. In addition, farmers' period of residence in the area is significantly influence the provision of extension services $\left(\chi^{2}=10.619, \mathrm{P}=\right.$ 0.014). However, age, family size, educational level, landholding size, land size adequacy, period of residency, the involvement in local administration, farming system, sources of income, relative position in the sub-catchment of house head was not significantly influence about farmers' knowledge about the presence of SWC technologies. Moreover, our findings revealed that the farmers' knowledge on the introduced SWC technologies was significantly influenced by their age $\left(\chi^{2}\right.$ $=9.686, \mathrm{P}=0.046)$, farming systems $\left(\chi^{2}=8.017, \mathrm{P}=0.018\right)$, household income sources $\left(\chi^{2}=5.022, \mathrm{P}=0.025\right)$, and relative position in the sub-catchment $\left(\chi^{2}=\right.$ $18.856, \mathrm{P}=0.000)$.

In the study area, though not well organized and implemented improperly, farmers have been applied various types of SWC technologies to arrest soil erosion. The most common practices recognized by farmers are soil/stone bund, Fanya juu, cut-off drain, waterways, and afforestation. Soil bund is the most common and dominant SWC practices applied by farmers which is followed by Fanya juu. The potential of the newly introduced SWC technologies to improve land productivity and respondents' intention to maintain the constructed structures was significantly affected by household income sources $\left(\chi^{2}=4.102, \mathrm{P}=\right.$ $0.043)$, relative position $\left(\chi^{2}=8.776, \mathrm{P}=0.012\right)$. The chi square test result also revealed that farmers' perception on their responsibility of constructing and maintaining SWC technologies was found to be significantly influenced by sex of respondent $\left(\chi^{2}=5.091, \mathrm{P}=0.024\right)$, household income sources $\left(\chi^{2}=4.821, \mathrm{P}=\right.$ 0.028). Besides, our result also showed that the responsible body to construct and maintain the structures was significantly depends on $\operatorname{sex}\left(\chi^{2}=17.882, \mathrm{P}=\right.$ $0.000)$, landholding size $\left(\chi^{2}=23.734, \mathrm{P}=0.022\right)$, farming system $\left(\chi^{2}=17.281, \mathrm{P}\right.$ $=0.008)$, income sources $\left(\chi^{2}=17.281, \mathrm{P}=0.001\right)$, relative position in the watershed $\left(\chi^{2}=33.160, P=0.000\right)$. In the study sub-catchment, the status (degree) of use of improved SWC structures was assessed. Accordingly, the respondents' 
educational level $\left(\chi^{2}=23.663, \mathrm{P}=0.023\right)$, involvement in local administration $\left(\chi^{2}=31.436, \mathrm{P}=0.000\right)$, farming systems $\left(\chi^{2}=21.584, \mathrm{P}=0.001\right)$, sources of income $\left(\chi^{2}=9.357, \mathrm{P}=0.025\right)$ and relative position $\left(\chi^{2}=64.406, \mathrm{P}=0.000\right)$ as the farmers located in the downstream were found to be the best adopters of the newly introduced SWC technologies than the upper and the midstream ones. When farmers compared the problem of soil erosion in their farm land after conservation structures were built, it was found to be significantly influenced by landholding size adequacy $\left(\chi^{2}=26.143, \mathrm{P}=0.000\right)$. Moreover, the chi-square test result also indicated that respondents' adoption judgment of SWC measures was significantly influenced by sex $\left(\chi^{2}=12.590, \mathrm{P}=0.002\right)$. Similar findings elsewhere [24] [32] also confirmed that adoption of conservation practices alone may not lead to sustained land rehabilitation unless the technologies are utilized continuously.

\section{Conclusions}

The study was conducted to assess farmers' perception of soil erosion and adoption of SWC technologies in Geshy sub-catchment of Gojeb River Catchment, Ethiopia. The results indicated that almost all of the respondents perceived soil erosion as a serious land degradation. However, almost all of them confirmed that soil erosion can be controlled. The key causes of soil erosion that realized by them were deforestation due to agricultural expansion followed by farm land steepness. Soil erosion has resulted in the decline in land productivity, creation of rill and gullies on their farm land. In the sub-catchment, to overcome soil erosion problems, the majority of the respondents were actively participated in SWC activities voluntarily, taking into account participatory approach. It has become increasingly recognized that SWC technologies can only be achieved through participatory approach that genuinely involve farmers rather than by imposed top to down approach. Participation of the farmers should be a partnership leading towards a common goal rather than mistaking community mobilization which may entail failure that erodes farmer's self-reliance in government activities. Moreover, almost all of them are willing to adopt introduced SWC technologies and it has been perceived as the most efficient in arresting soil erosion.

In Geshy sub-catchment, the majorities of the farmers have already known and practiced various types of introduced SWC technologies (Soil bund, Fanya juu, cut-off drain, waterways, and afforestation) before the implementation of sustainable land management program. Besides frequent technical assistance, almost all of the respondents strongly believed that construction and maintenance of SWC activities is farmers' responsibility. Hence, almost all respondents (94.8\%) expressed their willingness to continue maintaining the established structures with their very good adoption judgment of technologies. Therefore, farm-level adoption of technologies is the decisive element for the success of a watershed management intervention. However, the study finding showed that 
construction of introduced SWC technologies was time-consuming, and high labour-demanding and needs frequent technical support for design construction for their sustainability. The most significant factors that need immediate concern for SWC activities are carefully designed and constructed structures with full farmers' participation derived from farmers' conviction. In addition to the investigation of farmers' perception of soil erosion and adoption option, the technical specification of SWC technologies should be evaluated in terms of design and their effects on soil-water resources and effectiveness in controlling erosion quantitatively.

\section{Acknowledgements}

This study was made possible by a research grant from the Sustainable Land Management program, Ministry of Agriculture and Natural Resources and Italian Contribution to the Education Sector Development Programme (ESDP) in collaboration with Haramaya University, Ethiopia. We are also indebted to the farmers and enumerators who took part in the survey as well as the anonymous reviewers and the editors for their valuable comments and suggestions.

\section{Conflicts of Interest}

The authors declare no conflicts of interest regarding the publication of this paper.

\section{References}

[1] Omuto, C.T., Balint, Z. and Alim, M.S. (2014) A Framework for National Assessment of Land Degradation in the Drylands: A Case Study of Somalia. Land Degradation and Development, 25, 105-119. https://doi.org/10.1002/ldr.1151

[2] Ezeaku, P.I. and Davidson, A. (2008) Analytical Situations of Land Degradation and Sustainable Management Strategies in Africa. Journal of Agriculture and Social Sciences, 4, 42-52.

[3] Torres, L., Abraham, E.M., Rubio, C., Barbero-Sierra, C. and Ruiz-Pérez M. (2015) Desertification Research in Argentina. Land Degradation and Development, 26, 433-440. https://doi.org/10.1002/ldr.2392

[4] Xie, L.W., Zhong, J., Chen, F.F., Cao, F.X., Li, J.J. and Wu L.C. (2015) Evaluation of Soil Fertility in the Succession of Karst Rocky Desertification Using Principal Component Analysis. Solid Earth, 6, 515-524.

https://doi.org/10.5194/se-6-515-2015

[5] Stringer, L.C. and Dougill, A.J. (2013) Channelling Science into Policy: Enabling Best Practices from Research on Land Degradation and Sustainable Land Management in Dryland Africa. Journal of Environmental Management, 114, 328-335. https://doi.org/10.5194/se-6-515-2015

[6] Reed, M. and Stringer, L. (2016) Land Degradation, Desertification and Climate Change: Anticipating, Assessing and Adapting to Future Change. Routledge, London. https://doi.org/10.4324/9780203071151

[7] Assefa, E. and Hans-Rudolf, B. (2016) Farmers' Perception of Land Degradation and Traditional Knowledge in Southern Ethiopia-Resilience and Stability. Land 
Degradation and Development, 27, 1552-1561. https://doi.org/10.1002/ldr.2364

[8] Nigussie, Z., Tsunekawa, A., Haregeweyn, N., Adgo, E., Nohmi, M., Tsubo, M., Aklog, D., Meshesha, D.T. and Abele, S. (2017) Farmers' Perception about Soil Erosion in Ethiopia. Land Degradation and Development, 28, 401-411.

https://doi.org/10.1002/ldr.2647

[9] Moges, A. and Holden, N.M. (2007) Farmers' Perception of Soil Erosion and Soil Fertility Loss in Southern Ethiopia. Land Degradation and Development, 18, 543-554. https://doi.org/10.1002/ldr.795

[10] Pulido, J. and Bocco, G. (2014) Local Perception of Land Degradation in Developing Countries: A Simplified Analytical Framework of Driving Forces, Processes, Indicators and Coping Strategies. Living Reviews in Landscape Research, 8, 4. https://doi.org/10.12942/lrlr-2014-4

[11] Gessesse, B., Bewket, W. and Bräuning, A. (2016) Determinants of Farmers' Tree-Planting Investment Decisions as a Degraded Landscape Management Strategy in the Central Highlands of Ethiopia. Solid Earth, 7, 639-650. https://doi.org/10.5194/se-7-639-2016

[12] Shiferaw, B. and Holden, S.T. (2000). Policy Instruments for Sustainable Land Management: The Case of Highland in Ethiopia. Agricultural Economics, 22, 217-232. https://doi.org/10.1111/j.1574-0862.2000.tb00071.x

[13] Holden, S.T., Bekele, S. and Pender, J. (2005) Policy Analysis for Sustainable Land Management and Food Security in Ethiopia. A Bio-Economic Model with Market Imperfections Research Report 140. International Food Policy Research Institute, Washington DC.

[14] Bewket, W. and Sterk, G. (2002) Farmer's Participation in Soil and Water Conservation Activities in the Chemoga Watershed, Blue Nile Basin, Ethiopia. Land Degradation and Development, 13, 189-200. https://doi.org/10.1002/ldr.492

[15] Tesfaye, A., Negatu, W., Brouwer, R. and van der Zaag, P. (2014) Understanding Soil Conservation Decision of Farmers in the Gedeb Watershed, Ethiopia. Land Degradation and Development, 25, 71-79. https://doi.org/10.1002/ldr.2187

[16] Haregeweyn, N., Tsunekawa, A., Nyssen, J., Poesen, J., Tsubo, M., Meshesha, D.T., Schütt, B., Adgo, E. and Tegegne, F. (2015) Soil Erosion and Conservation in Ethiopia: A Review. Progress in Physical Geography, 39, 750-774. https://doi.org/10.1177/0309133315598725

[17] Hurni, K., Zeleke, G., Kassie, M., Tegegne, B., Kassawmar, T., Teferi, E., Moges, A., Tadesse, D., Ahmed, M., Degu, Y., et al. (2015) The Economics of Land Degradation. Ethiopia Case Study. Soil Degradation and Sustainable Land Management in the Rainfed Agricultural Areas of Ethiopia. Report for the Economcs of Land Degradation Initiative, 94 .

[18] Bewket, W. and Teferi, E. (2009) Assessment of Soil Erosion Hazard and Prioritization for Treatment at the Watershed Level: Case Study in the Chemoga Watershed, Blue Nile Basin, Ethiopia. Land Degradation and Development, 20, 609-622. https://doi.org/10.1002/ldr.944

[19] Gelagay, H.S. and Minale, A.S. (2016) Soil Loss Estimation Using GIS and Remote Sensing Techniques: A Case of Koga Watershed, Northwestern Ethiopia. International Soil and Water Conservation Research, 4, 126-136. https://doi.org/10.1016/j.iswcr.2016.01.002

[20] Denboba, M.A. (2005) Forest Conversion-Soil Degradation-Farmers' Perception Nexus: Implications for Sustainable Land Use in the Southwest of Ethiopia. Ecology and Development Series, No. 26, 1-149. 
[21] Tefera, B. and Sterk, G. (2010) Land Management, Erosion Problems and Soil and Water Conservation in Fincha'a Watershed, Western Ethiopia. Land Use Policy, 27, 1027-1037. https://doi.org/10.1016/j.landusepol.2010.01.005

[22] Haregeweyn, N., Tsunekawa, A., Poesen, J., Tsubo, M., Meshesha, D.T., Fenta, A.A., Nyssen, J. and Adgo, E. (2017) Comprehensive Assessment of Soil Erosion Risk for Better Land Use Planning in River Basins: Case Study of the Upper Blue Nile River. Science of the Total Environment, 574, 95-108. https://doi.org/10.1016/j.scitotenv.2016.09.019

[23] Bekele, W. and Lars, D. (2003) Soil and Water Conservation Decision Behavior of Subsistence Farmers in the Eastern Highlands of Ethiopia: A Case Study of the Hunde-Lafto Area. Ecological Economics, 46, 437-451. https://doi.org/10.1016/S0921-8009(03)00166-6

[24] Amsalu, A. and de Graaff, J. (2006) Farmers' Views of Soil Erosion Problems and Their Conservation Knowledge at Beressa Watershed, Central Highlands of Ethiopia. Agriculture and Human Values, 23, 99-108. https://doi.org/10.1007/s10460-005-5872-4

[25] Bewket, W. (2007) Soil and Water Conservation Intervention with Conventional Technologies in Northwestern Highlands of Ethiopia: Acceptance and Adoption by Farmers. Land Use Policy, 24, 404-416. https://doi.org/10.1016/j.landusepol.2006.05.004

[26] Mushir, A. and Kedru, S. (2012) Soil and Water Conservation Management through Indeigenous and Traditional Practices in Ethiopa: A Case Study. Ethiopian Journal of Environmental Studies and Management, 5, 356-365. https://doi.org/10.4314/ejesm.v5i4.3

[27] Abebe, T. (2013) Soil Analysis, Mapping and Interpretation of the World Bank Funded 20 SLMP Watersheds of Ethiopia, Final Soil Report. Sustainable Land Management, Ministry of Agriculture, 290.

[28] Kothari, C.R. (2004) Research Methodology: Methods \& Techniques. New Age International Publishers.

[29] IBM Corp. Released (2011) IBM SPSS Statistics for Windows (Version 20.0). IBM Corp., Armonk.

[30] Central Statistical Agency (CSA) Federal Democratic Republic of Ethiopia (2007) The 2007 Population and Housing Census of Ethiopia, Addis Ababa.

[31] Biratu, A.A. and Desale, K.A. (2016) Farmers' Perception of Soil Erosion and Participation in Soil and Water Conservation Activities in the Gusha Temela Watershed, Arsi, Ethiopia. International Journal of River Basin Management, 14, 329-336. https://doi.org/10.1080/15715124.2016.1167063

[32] Zegeye, A.D., Tammo, S., Steenhuis, R.W., Blake, S., Kidnau, Amy, S.C. and Dadgari, F. (2010) Assessment of Soil Erosion Processes and Farmer Perception of Land Conservation in Debre Mewi Watershed near Lake Tana, Ethiopia. Ecohydrology and Hydrobiology, 10, 297-306. https://doi.org/10.2478/v10104-011-0013-8

[33] Weldemariam, D., Kebede, M., Taddesse, M. and Gebre, T. (2013) Farmers' Perceptions' and Participation on Mechanical Soil and Water Conservation Techniques in Kembata Tembaro Zone: The Case of Kachabirra Woreda, Ethiopia. International Journal of Advanced Structures and Geotechnical Engineering, 2, 4.

[34] Bewket, W. (2011) Farmers' Knowledge of Soil Erosion and Control Measures in the Northwestern Highlands of Ethiopia. African Geographical Review, 30, 53-70.

[35] Miheretu, B.A. (2014) Farmers' Perception and Adoption of Soil and Water Con- 
servation Measures: The Case of Gidan Wereda, North Wello, Ethiopia. Journal of Economics and Sustainable Development, 5, 24.

[36] Tadesse, M. and Belay, K. (2004) Factors Influencing Adoption of Soil Conservation Measures in Southern Ethiopia: The Case of Gununo Area. Journal of Agriculture and Rural Development in the Tropics and Subtropics, 105, 49-62.

[37] Atnafe, A.D., Husen, M.A. and Demeku, M.A. (2015) Determinants of Adopting Techniques of Soil and Water Conservation in Goromti Watershed, Western Ethiopia. Journal of Soil Science and Environmental Management, 6, 168-177.

[38] Nyssen, J., Poesen, J. and Deckers, J. (2009) Land Degradation and Soil and Water Conservation in Tropical Highlands. Soil and Tillage Research, 103, 197-202. https://doi.org/10.1016/j.still.2008.08.002

[39] Demelash, M. and Stahr, K. (2010) Assessment of Integrated Soil and Water Conservation Measures on Key Soil Properties in South Gonder, North-Western Highlands of Ethiopia. Journal of Soil Science and Environmental Management, 1, 164-176.

[40] Kessler, C.A. (2006) Decisive Key-Factors Influencing Farm Households' Soil and Water Conservation Investments. Applied Geography, 26, 40-60.

https://doi.org/10.1016/j.apgeog.2005.07.005 